\title{
Distal Bile Duct Cancer pT2 TNM Finding v8
}

National Cancer Institute

\section{Source}

National Cancer Institute. Distal Bile Duct CancerpT2 TNM Finding v8. NCI Thesaurus.

Code C134801.

Distal bile duct cancer with tumor invading the bile duct wall with a depth of 5-12 $\mathrm{mm}$.

(from AJCC 8th Ed.) 